\title{
The Political Economy of FEMA: Did Reorganization Matter?
}

\author{
Russell S. Sobel, Christopher J. Coyne, Peter T. Leeson*
}

\begin{abstract}
This paper investigates the political economy of FEMA after its post-9/11 merger with the Department of Homeland Security. Using panel data for the post-DHS merger but pre-Katrina period, we examine how FEMA's much-debated reorganization has impacted the strong political influences on disaster declaration and relief spending that existed before FEMA's reorganization. We find that although politically-important states for the president continue to have a higher rate of disaster declaration, disaster expenditures are no longer higher in states with congressional representation on FEMA oversight committees. These results suggest reorganization has reduced some of the political pressures within FEMA.
\end{abstract}

JEL Codes: D7, H5

Keywords: bureaucracy, congressional oversight, Department of Homeland Security, Federal Emergency Management Agency.

\footnotetext{
* Russell S. Sobel (russell.sobel@mail.wvu.edu) and Christopher J. Coyne (chris.coyne@mail.wvu.edu), West Virginia University, Department of Economics, P.O. Box 6025, Morgantown, WV 26506-6025. Peter T. Leeson (pleeson@gmu.edu), George Mason University, Department of Economics, Fairfax, VA 22030.
} 


\section{The Political Economy of FEMA: Did Reorganization Matter?}

\section{Introduction}

In February 2003 the Federal Emergency Management Agency (FEMA) was placed under the authority of the Department of Homeland Security (DHS) under a federal government reorganization plan. The impetus behind the reorganization was the 9/11 attacks on the World Trade Center and Pentagon. Following the attacks, several members of Congress, as well as the White House, called for a radical reorganization of the U.S. government's anti-terrorism and anti-disaster programs. The goal of the restructuring was to increase the efficiency and responsiveness of government agencies in preventing and responding to future terrorist attacks.

The potential impact of FEMA's merger with the DHS has been hotly debated. For instance, a report by the Brookings Institute that discussed the potential merger argued that "While a merged FEMA might become highly adept at preparing for and responding to terrorism, it would likely become less effective in performing its current mission in case of natural disasters as time, effort and attention are inevitably diverted to other tasks within the larger organization” (Daalder 2002: 24). In contrast, former FEMA Director Michael Brown has argued that Americans would be better served under the new organizational structure because it would create a "FEMA on steroids" that was faster, more responsive and more efficient (quoted in Elliston 2004).

In addition to questions about the merger's potential impact on FEMA's effectiveness in delivering disaster relief, FEMA's reorganization under the DHS has raised another important question: How has the new organization impacted the political economy of FEMA disaster relief decisions? Given that the dynamics governing the political side of FEMA-related political 
economy have clearly changed rather dramatically since the merger, it is important to investigate how FEMA's post-9/11 reorganization has impacted the federal government's disaster relief decision making.

Following Hurricane Katrina in 2005, a flurry of new research has begun to examine the reasons behind FEMA's mistakes and mishandling of disaster relief in the post-reorganization period (see Congleton 2005, Shughart 2005, Sobel and Leeson 2005, Chappell et al. 2007, Ewing and Sutter 2007, Guion, Scammon and Borders 2007, Leeson and Sobel 2007). Prior to this work, earlier research by Garrett and Sobel (2003) examined the political economy of FEMA. Using data for the period 1991 through 1999, prior to FEMA's reorganization, this research found that political pressures were strongly at work in both the disaster declaration process, due to the influence of the president, and in the allocation of FEMA spending across states, due to the influence of congressional oversight. Between 1991 and 1999, the president declared more disasters in states that were politically important to him and states with greater representation on FEMA's congressional oversight committees received more FEMA relief, controlling for other factors that might affect this, than states with less such representation.

Using panel data on presidential disaster declarations and FEMA disaster expenditures in the U.S. states for the post-DHS merger but pre-Katrina, 2003-2005, period, this paper examines the political economy of the FEMA reorganization. We investigate two competing hypotheses regarding the impact of FEMA's reorganization under the DHS on the political allocation of FEMA resources. The first hypothesis suggests that FEMA's reorganization has been essentially unimportant for the allocation of FEMA relief. According to this view, congressional and presidential influences continue to strongly affect the rate of presidential disaster declaration and the disbursement of federal disaster relief payments. The second, and alternative, hypothesis 
suggests that FEMA's recent reorganization under the DHS has reduced the political manipulation of FEMA resources. According to this competing view, at least a part of the previous political influences and pressures that FEMA was subjected to before its reorganization under DHS have been severed or weakened. Because FEMA's reorganization has not affected the president's relationship to the FEMA disaster declaration process, the president should be expected to continue to exert political influence on disaster declaration. However, because of the different relationship between FEMA and its congressional oversight committees under the reorganization, the impact of congressional oversight may have diminished following FEMA's merger with the DHS. In short, according to this second hypothesis, the merger has increased the bureaucracy associated with congressional oversight, weakening the influence of any one committee over FEMA, and has placed its relatively small and inflexible budget within the much larger and more flexible DHS budget making it a less likely political target.

This paper empirically investigates these competing hypotheses and finds results that are consistent with the second one. We find that states that are politically important to the president continue to have a higher rate of disaster declaration. However, we find that following the merger of FEMA with the DHS, disaster expenditures are no longer higher in states having congressional representation on the congressional oversight committees, implying the presence of less political pressures within FEMA than existed prior to DHS reorganization.

Our explanation for this result is that the merger of FEMA with the DHS introduced numerous new layers and unclear lines in the oversight process, and also created power struggles among the various oversight committees responsible for FEMA resource allocation. A new and interesting political dynamic is at work at FEMA-one in which congressional oversight 
committees have less direct influence in the post-merger period. The situation is best explained by exploiting insights from Tullock’s (1965) economic analysis of bureaucracy.

Our analysis proceeds as follows. We begin by providing a brief history of the organizational structure of FEMA and how disaster relief policy has evolved. We then delve deeper into the political economy present at the main FEMA relief decision nodes when political pressures may enter into internal decision making. These two nodes are the decision to declare a disaster and then the subsequent disaster funding level. We then present our empirical results and a discussion of the current political economy of FEMA based on our findings. We conclude with the implications of our analysis.

\section{FEMA and Sources of Political Influence}

FEMA was created via executive order by President Carter in 1979. The new agency was created by merging several existing disaster-related agencies together including the Federal Insurance Administration, the National Fire Prevention and Control Administration, the National Weather Service Community Preparedness Program, the Federal Preparedness Agency of the General Services Administration and the Federal Disaster Assistance Administration activities from the U.S. Department of Housing and Urban Development. FEMA's mission was "to lead America to prepare for, prevent, respond to and recover from disasters with a vision of " $\mathrm{A}$ Nation Prepared'.,1

The operations of FEMA are governed by the Robert T. Stafford Disaster Relief and Emergency Assistance Act (Public Law 100-707) which amended the Disaster Relief Act of 1974 (Public Law 93-288). The Stafford Act “constitutes the statutory authority for most

\footnotetext{
${ }^{1}$ FEMA website: http://www.fema.gov/
} 
Federal disaster response activities especially as they pertain to FEMA and FEMA programs” and is meant to provide guidelines for the U.S. government to deliver disaster relief to its citizens. The Act declares that the president has unilateral authority to declare an "emergency" which then triggers federal aid to supplement relief from state and local agencies. The reason behind the unilateral power granted to the president is to increase the response of the federal government to disasters. Aid for disasters is housed in the Disaster Relief Fund, which is controlled by the DHS. The funds allocated to the Disaster Relief Fund remain available until they are expended.

Because FEMA is a federal agency, congress has a responsibility for the oversight of its operations. Prior to the merger with the DHS, FEMA was an independent entity with direct congressional oversight. Following the 2003 merger, congressional oversight of FEMA has now become indirect. Congressional oversight now takes place over the DHS of which FEMA is one part. FEMA's annual budget varies between $\$ 2$ and $\$ 8$ billion. While this is a substantial sum, it is only a minor part of the Department of Homeland Security’s $\$ 40$ billion-plus total annual budget. After the reorganization, FEMA moved down in the oversight process. The DHS is now subjected to direct congressional oversight and FEMA essentially became lost in the mix. As we will discuss in more detail, the size of the DHS, combined with a lack of clear oversight, has led to political infighting and turf battles over control of the larger DHS budget (see Foley and Rudman 2004). In what follows, we consider the president and congressional oversight as two potential avenues of political influence on the operations of FEMA within DHS. 


\section{Presidential Influence on FEMA}

The first avenue of influence over FEMA is the process of disaster declaration. Under the Stafford Act there is no clear guideline for when an event is 'severe' enough to be declared as an official disaster. Instead the president is given unilateral discretion over this process. When a disaster occurs, the governor of the affected state contacts the president requesting a disaster declaration and the president then makes a final decision as to whether or not to declare a disaster.

On average, the president generally grants slightly under three-fourths of such requests. ${ }^{2}$ From 1981 to 2006 the average number of disasters declared per year was 40, and while a rare few of these were for weather events such as Hurricane Katrina, which were clearly major disasters, the vast majority were declared for 'severe' snowstorms, rainstorms, wind, and other smaller scale weather events.

The basic public choice model makes two specific predictions with respect to this process. First, presidents should be more likely to declare disasters during reelection years. Second, presidents should be more likely to declare disasters in those states that are more politically important. Both of these hypotheses were confirmed for the 1991-1999 data (see Garrett and Sobel 2003). Here we examine these hypotheses using data for every disaster that occurred from post-reorganization in 2003, up to but not including Hurricane Katrina in 2005. A description of our data and data sources is available in Appendix I. Our null hypothesis is that the reorganization has had little or no impact on this part of the political pressure on the disaster relief process since the reforms mainly impacted operational and budgetary oversight through congressional channels.

\footnotetext{
${ }^{2}$ Source of percentage of presidential declarations: Public Entity Risk Institute database of Presidential Disaster Declarations (http://www.peripresdecusa.org/mainframe.htm).
} 
We begin by examining this hypothesis about reelection years the raw data, which presents a striking pattern. Figure 1 depicts the number of disasters declared for each of the past four presidents. The black bar indicates the president's reelection year.

\section{[Insert Figure 1 about here]}

Figure 1 suggests a clear and consistent trend: each president has declared the most disasters during his reelection year. Importantly, this result not only holds across time, but also across political affiliation. Further, this trend has continued past the 1999 data into the present.

Econometrically, we test both hypotheses following the technique outlined in Garrett and Sobel (2003), which uses a Poisson model to properly handle the count nature of the dependent variable, which is the number of disasters declared in state $i$ in year $t$. Tests for overdispersion confirmed the use of the Poisson over the negative binomial version of this model (which was also the case in the previous study by Garrett and Sobel using the pre-DHS merger data). Our independent variables of interest are a dummy variable to denote the 2004 presidential reelection year and Garrett and Sobel's measure of the electoral vote importance of each state. To construct the latter variable, each state's electoral votes are multiplied by the political closeness of each state in the presidential election. ${ }^{3}$ The resulting measure captures the extent of each state’s “battle-ground” status in the 2004 election contained in our sample period.

\footnotetext{
${ }^{3}$ Expected electoral votes for each state $i$, calculated as Electoral $\operatorname{Votes}_{\mathrm{i}}{ }^{*} Y_{\mathrm{i}}$, where $Y_{\mathrm{i}}=1-4^{*}\left(X_{\mathrm{i}}-0.5\right)^{2}$, where $X_{\mathrm{i}}$ is the percent of the 2004 popular vote in state $i$ that eventually went for Kerry. Thus, if the state was a battleground state in the 2004 election (the vote shares approaching 50-50), then the electoral importance of that state is equal to the state's number of electoral votes, whereas a zero or 100 percent vote share in a state results in an electoral importance of zero for the state regardless of the number of electoral votes carried by the state.
} 
In addition to these variables, we also include several other variables that proxy the political importance of states, such as an indicator of whether the state's governor is of the same political party as the president and the percent of the state's congressional delegation that is the same party as the president. Our controls include the insurance property claims in the state and year (to control for disaster severity), per capita income, and regional and year fixed effects. Table 1 presents the results of these regressions.

[Insert Table 1 about here]

The results in Table 1, using data for 2003 (post-DHS move) to 2005 pre-Katrina, show virtually identical results to those found previously using 1991-1999 data. The reelection year dummy is positive and significant at the 1 percent level. The electoral importance variable is also strongly significant and positive. The other political variables are insignificant. Presidential declarations remain statistically uncorrelated with the political party of the state's governor and congressional delegation. Similarly, the president remains more likely to declare a disaster if the state has lower per capita income. These results lead us to conclude that presidential politics are still at play in the post DHS reorganization as strongly as they were before this reorganization. Presidents remain more likely to declare disasters in election years and in states that are potentially more politically important after the DHS merger.

\section{The Influence of Congressional Oversight on FEMA}

The second source of political influence in the disaster relief process is in the level of FEMA disaster relief spending given a disaster has been declared by the president. Garrett and Sobel 
(2003) found strong evidence that congressional oversight significantly influenced FEMA spending. In particular, states with representatives on House oversight committees for FEMA tended to get significantly more funding per disaster, ceteris paribus.

The theory behind this finding lies in the literature on the "congressional dominance model," which posits that bureaus will respond to the desires of Congress. Moe $(1987,1997)$, Weingast and Moran (1983) and Weingast (1984) discuss how the model predicts that congressional committees that have both budgetary and oversight responsibilities will result in the tendency of bureaucrats to adopt and implement the policy preferences of the legislators. The underlying logic is that bureaucrats want to maximize their budget in future periods and do so by satisfying the desires of legislatures in the present period. ${ }^{4}$

A growing literature empirically tests the validity of the congressional dominance theory. For instance, Wright (1974), Anderson and Tollison (1991) and Couch and Shughart (1997) analyze the connection between New Deal state spending and congressional power. These studies find a positive correlation between New Deal spending across states and congressional power. They also find a positive relationship between state spending and the importance of a state's electoral vote in the next presidential election. Faith et al. (1982) find that case rulings of the Federal Trade Commission (FTC) tend to be more favorable for firms whose headquarters are located in a district having representation on the FTC congressional oversight committees. Grier (1987) finds that the policy of the Federal Reserve is influenced by leadership changes in the Senate Banking Committee. Young et al. (2001) find that audit rates by the Internal Revenue Service (IRS) are lower in states that have political importance in the next presidential election.

\footnotetext{
${ }^{4}$ For a detailed review of the literature on bureaucracy, as well as discussion of what bureaucrats maximize, see Niskanen (2001).
} 
They also find that IRS audit rates are lower in the congressional districts of members of congressional committees responsible for oversight of the IRS.

Each of these studies supports the predictions of the congressional dominance model, as does the existing research on the political economy of FEMA. However, because of the 2003 reorganization, the relationship between FEMA and congressional oversight committees has undergone a significant change. Prior to the merger with the DHS, FEMA was an independent agency with a total of nine long-standing oversight subcommittees. With the reorganization, the previously independent FEMA became a relatively small part of the third largest department in the U.S. federal government with its own complicated set of new oversight committees.

In a 2004 report on the congressional oversight of the DHS, former Speaker of the House Thomas Foley and former senator Warren Rudman noted that every senator as well as 412 of 435 House members has some degree of influence over the operations of the DHS (2004: 2). The result is that "very few members of Congress have any real incentive to acquire expertise...beyond their committee’s or subcommittee’s domain” (2004: 2). Further, it is unclear what committees have what oversight responsibilities meaning that DHS officials must allocate significant time and resources answering to numerous committee members without understanding their role or how they fit into the larger oversight process.

Tullock’s (1965) economic analysis of bureaucratic organizations provides insight into how the many bureaucratic layers of DHS oversight result in dysfunction. ${ }^{5}$ Tullock (1965) emphasizes that bureaucracies suffer from the dual problems of information distortion and incentive compatibility. On the one hand, as the chain of command within a bureaucracy gets larger, it is more likely that information will be distorted. On the other hand, as bureaucracies

\footnotetext{
${ }^{5}$ Other important studies of the economics of bureaucracy include Mises (1944), Downs (1967) and Niskanen (1971).
} 
become more decentralized - which lessens the problem of information distortion - it becomes increasingly difficult to ensure that the incentives of all the decentralized nodes are aligned in the pursuit of the broader overarching goal. When there are numerous and separate bureaucracies the result can be in-fighting and conflict, as each separate entity seeks to maintain and increase its position of power. While decentralizing bureaucracy reduces information distortions, it also requires that clearly-delineated rules are established to ensure that incentives are aligned across the decentralized nodes. Tullock concludes that the difficulty of finding a simultaneous solution to the information and incentives problems significantly constrains the effective reach of bureaucracies.

In the context of FEMA and the DHS, the 2003 merger created a set of incentives that generated perverse outcomes along the lines of Tullock's analysis. While oversight committees are supposed to serve as a key check on the DHS to ensure that it performs it stated duties, the incentives created by the magnitude of the oversight bureaucracy have resulted in in-fighting and turf wars with parties having little incentive to cede control or power. Along these lines, Foley and Rudman note that the "fragmentation [of oversight] preserves rivalries and cultural barriers that the creation of the Department [of Homeland Security] was intended to eliminate; and it prevents DHS from acting as a single, well-coordinated team.” The result is "a Department of Homeland Security that is hamstrung by a system of Congressional oversight that drains departmental energy and invites managerial circumvention” (Foley and Rudman 2004: 1-2).

The growth of bureaucracy associated with the increased oversight of the reorganized DHS has significant implications for congressional influence in the allocation of FEMA funds. Prior to the reorganization, when FEMA was an independent agency, the allocation of disaster payments was relatively higher in states represented on oversight committees. However, with 
the introduction of numerous new levels of bureaucracy, there is general confusion over what oversight committees have control and power. In other words, because there are no clear lines of oversight, the officials of the DHS and the departments within the DHS must answer to "many masters” where no single master has strong influence or control. Moreover, the numerous layers of bureaucracy result in conflict between oversight committees that are supposed to be coordinated on the common goal of ensuring that the DHS delivers on its mission. This stands in stark contrast to the period when FEMA was an independent agency and had its own set of longstanding oversight committees. Before the merger with DHS, the oversight of FEMA was clear, as were the sources of congressional influence.

In addition, even if the new DHS oversight committees do receive favoritism in DHS spending, this could much more easily be accomplished through redirecting even bigger pots of money controlled under other DHS programs. FEMA represents only around 10 percent of the total DHS budget and virtually every other DHS program related to anti-terrorism has more expenditure flexibility and is easy to target geographically to a congressional district. This should make FEMA funds a less likely political target from congressional oversight than in the past.

Given the magnitude and confusion of congressional oversight in the post-DHS merger period, we attempt to test for whether congressional influence was still related to FEMA spending in the post-DHS but pre-Katrina era. In order to carry out our analysis we focus on the four main oversight committees identified by Foley and Rudman (2004). The committees identified in the Foley and Rudman report are: House Appropriations on Homeland Security, Senate Appropriations on Homeland Security, House Select Homeland Security and the Senate 
Committee on Homeland Security and Government Affairs. Table 2 presents the average number of members on each of these committees.

[Insert Table 2 about here]

The House and Senate Appropriations committees control FEMA's budget. FEMA's appropriation comes from the homeland security appropriations bill and the appropriations committees can appropriate more than is authorized or add in earmarks for specific FEMA programs. For example, a committee member might add an amendment to secure funds for a specific project even if the president did not request this money and the Homeland Security committee did not authorize the money. The House Select Homeland Security committee was initially established in 2002 and initially charged with developing "recommendations and report to the House on such matters that relate to the establishment of a department of homeland security." After accomplishing this task, the committee shifted focus to oversight. Because the DHS is part of the executive branch, it requires congressional oversight and the purpose of the House Select committee is to fulfill this role. Finally, the Senate Committee on Homeland Security and Government Affairs possessed the primary jurisdiction over the initial creation of the DHS and is the main oversight committee of the U.S. Senate.

The question we wish to answer is whether congressional oversight now plays a smaller role in FEMA spending patterns because of the unclear and unsettled oversight structure, and the relatively small share FEMA has become of the pool of DHS spending. Following Garrett and Sobel (2003) we estimate Tobit models of FEMA spending using the updated data from 20032005. Appendix I contains a detailed a description of this data and its sources. A Tobit model is 
necessary here because the dependent variable-FEMA spending in state $i$ in year $t$ - is censored at zero, with some states having no disasters declared in a particular year and thus no funding, while others have disasters declared and then a positive value for the dependent variable. We follow the original specification used in Garrett and Sobel, simply redefining the committees used in the regressions. The regression is run in several ways. First, we use each state's total number of legislators on all oversight committees at that point in time as our key independent variable. Second, we split this variable into two variables for House and Senate. Finally, we use each state's total number of legislators on oversight committees, considering each individual oversight committee separately. Our control variables include insurance property claims, number of disasters declared, and regional and year dummies.

[Insert Tables 3 and 4 about here]

Tables 3 and 4 present the results of these regressions. Table 3 shows the coefficient estimates, which measure the impact of each variable given a disaster has been declared. Table 4 shows the marginal effects, which also include any impact the underlying variable has on the zero/one nature of the problem-in other words, how it changes the unconditional expected value of disaster funding.

We find that all measures of congressional oversight are insignificant in all specifications. Thus, during the post-DHS merger (but pre-Katrina) period, there are no significant correlations between the levels of FEMA spending and membership on the major FEMA oversight committees in the U.S. Congress. 
Thus, the reorganization of FEMA under the Department of Homeland Security in 2003 did indeed reduce the influence of congressional politics on the distribution of FEMA funding. While the data on post-Katrina FEMA spending is still being generated, we did undertake a cursory analysis of evacuee funding across states and found no statistically significant results for congressional influence here either. Thus, our results seem to suggest that congressional politics likely played a minor to nonexistent role in FEMA spending decisions in the wake of Hurricane Katrina, and that this will likely continue to be unimportant into the future as long as the current organizational structure remains in place.

\section{Concluding Remarks}

Our analysis leads to several conclusions. First, the channel of political influence coming from the president, who is responsible for making decisions to actually declare a disaster, is as much at play today following the reorganization of FEMA under the DHS as it was before this merger. This makes sense because, as we discuss above, the structure of this part of the disaster relief process was unaffected by the merger. When it comes to the chief executive's decision making about natural disasters, FEMA relief continues to be decided largely on political grounds. In presidential reelection years and in states more politically important to the president, the president declares more natural disasters, allowing the FEMA money to flow when and where it will help him most in the reelection.

However, the other potential channel of political influence that has historically played a role in determining the allocation of FEMA resources—congressional oversight-appears to have been reduced (and perhaps severed) by FEMA's recent reorganization under the DHS. This is not because political actors have become less self interested as a result of FEMA's 
reorganization. Instead, by introducing a complex and unclear array of congressional committees with overlapping areas of oversight over the DHS and thus over FEMA, it appears that this reorganization has simply diminished the power and importance of any particular committee with FEMA oversight capacity. In addition, because FEMA represents only around 10 percent of the total DHS budget, and virtually every other DHS program has more expenditure flexibility and is easier to target geographically to a congressional district, FEMA funds are predictably a lower priority political target from legislators on congressional oversight committees.

Our analysis does not investigate other potentially important changes following from FEMA's reorganization under the DHS. Future research should explore, for instance, whether the effectiveness of FEMA-provided disaster relief has been improved or inhibited by the merger. However, this paper's findings do provide evidence regarding one indirect channel through which FEMA's reorganization might impact this. To the extent that FEMA resources are most effective when decisions regarding their allocation are made on the basis of actual need as opposed to on political grounds, by severing one of the traditionally-important channels of political influence over FEMA resources, FEMA's reorganization under the DHS may improve FEMA disaster assistance effectiveness, or at least reduce its harmfulness discussed by others. However, it is important to point out that to the extent that this in fact the case, the actual reason for such improvement is not among those suggested by proponents of the reorganization. Ironically, by cutting clear and identifiable channels of political influence, the unwieldy and incoherent bureaucratic mess generated as a result of the FEMA/DHS merger may actually have unintentionally prevented politics from trumping need in making FEMA relief-related resource allocations. 
Of course, this does not necessarily follow from our findings. It could be, for instance, that although congressional-based political influence has been removed through the merger, FEMA relief is getting tied up in the bureaucratic tangle or misdirected in alternative ways as a result of the reorganization. Further, other traditional problems of increased bureaucracy, which might be present as a result of FEMA's merger with the DHS, might also hamper the effectiveness of FEMA-provided disaster relief under the new organization. ${ }^{6}$ Future work should explore these and related questions.

\footnotetext{
${ }^{6}$ On the problems of bureaucratic management and economic calculation, see Mises (1944).
} 


\section{References}

Anderson, Gary M. and Richard D. Tollison. 1991. "Congressional Influence and Patterns of New Deal Spending, 1933-1939,” Journal of Law and Economics 34(1): 161-175.

Chappell, William F., Richard G. Forgette, Davide A. Swanson and Mark V. Van Boening. (2007). "Determinates of Government Aid to Katrina Survivors: Evidence from Survey Data,” Southern Economic Journal, 74(2): 344-362.

Congleton, Roger D. 2005. "The Story of Katrina: New Orleans and the Political Economy of Catastrophe,” Public Choice 127(1-2): 5-30.

Couch, Jim F. and William F. Shughart II. 1997. The Political Economy of the New Deal. Cheltenham, U.K. and Northampton, MA: Edward Elgar.

Daalder, Ivo H., I. M. Destler, James M. Lindsay, Paul C. Light, Robert E. Litan, Michael E. O’Hanlon, Peter R. Orszag, and James B. Steinberg. 2002. Assessing the Department of Homeland Security, Brookings Institution, Washington, D.C.

Department of Homeland Security. 2005. Budget in Brief: Fiscal Year 2005. Washington, D.C. Available online: http://www.dhs.gov/xlibrary/assets/FY_2005_BIB_4.pdf.

Downs, Anthony. 1967. Inside Bureaucracy. Boston: Little, Brown.

Elliston, Jon. “A Disaster Waiting to Happen,” The Independent Weekly, September 22.

Ewing, B.T. J.B. Kruse and D. Sutter. (2007). "Hurricanes and Economic Research: An Introduction to the Hurricane Katrina Symposium,” Southern Economic Journal, 74(2): 315-325.

Faith, Roger L., Donald R. Leavens, and Robert D. Tollison. 1982. “Antitrust Pork Barrel.” Journal of Law and Economics, 25(2): 329-42.

Foley, Thomas and Warren Rudman. 2004. "Untangling the Web: Congressional Oversight and the Department of Homeland Security," Center for Strategic and International Studies, Washington, D.C.

Garrett, Thomas A. and Russell S. Sobel. 2003. "The Political Economy of FEMA Disaster Payments,” Economic Inquiry, 41(3): 496-509.

Grier, Kevin B. 1987. "Presidential Elections and Federal Reserve Policy: An Empirical Test.” Southern Economic Journal 54: 475-486.

Guion D.T., D.L. Scammon, and A.L. Borders (2007). "Weathering the Storm: A Social Marketing Perspective on Disaster Preparedness and Response with Lessons from Hurricane Katrina,” Journal of Public Policy and Marketing, 26: 20-32. 
Leeson, Peter T. and Russell S. Sobel. 2007. "Weathering Corruption,” Journal of Law and Economics, forthcoming.

Mises, Ludwig von. 1944. Bureaucracy. New Haven: Yale University Press.

Moe, Terry M. 1987. "An Assessment of the Positive Theory of Congressional Dominance,” Legislative Studies Quarterly 12: 472-520.

. "The Positive Theory of Congressional Dominance," in Perspectives on Public Choice: A Handbook, D.C. Mueller (ed.) New York: Cambridge University Press, pp. 455-480.

Niskanen William A. 1971. Bureaucracy and Representative Government. Aldine: Atherton. . 2001. "Bureaucracy,” In, William F. Shughart and Laura Razzoline (eds), The Elgar Companion to Public Choice. United Kingdom: Edward Elgar, pp. 258-270.

Shughart, William. F. 2005. "Katrinanomics: The Politics and Economics of Disaster Relief," Public Choice 127(1-2): 31-53.

Sobel, Russell S. and Peter T. Leeson. 2005. "Government's Response to Hurricane Katrina: A Public Choice Analysis,” Public Choice 127(1-2): 55-73.

Tullock, Gordon. 1965 [2005] The Politics of Bureaucracy. In, Charles Rowley (ed), The Selected Works of Gordon Tullock, Volume 6: Bureaucracy. Liberty Fund: Indianapolis, pp13-235.

Weingast, Barry R. 1984. “The Congressional-bureaucratic System: a Principal Agent Perspective (with applications to the SEC),” Public Choice 44(1): 147-91.

Weingast, Barry R. and Mark J. Moran.1983. "Bureaucratic Discretion or Congressional Control? Regulatory Policy-making by the Federal Trade Commission,” Journal of Political Economy 91(5): 765-800.

Young, Marilyn, Michael Reksulak and William F. Shughart II. 2001. "The Political Economy of the IRS,” Economics and Politics, 13(2): 201-20. 
TABLE 1

Factors Impacting the Rate of Presidential Disaster Declaration; Poisson Regressions, Poisson Coefficients

\begin{tabular}{lccc}
\hline \multicolumn{1}{c}{ Variable } & Model (1) & Model (2) & Model (3) \\
\hline Constant & 1.352 & 1.227 & 1.311 \\
& $(1.471)$ & $(1.295)$ & $(1.323)$ \\
Insurance property claims from disasters per & 0.171 & 0.202 & 0.145 \\
capita (\$) & $(0.959)$ & $(1.086)$ & $(0.773)$ \\
Per capita income & $-0.647^{* *}$ & $-0.660^{* *}$ & $-0.791^{* * *}$ \\
Percent of Congress same party as president & $(2.491)$ & $(2.487)$ & $(2.784)$ \\
& -- & 0.501 & 0.404 \\
Governor from same political party as president & -- & $(1.208)$ & $(0.927)$ \\
Electoral Importance & --0.105 & -0.968 \\
& & $(0.057)$ & $(0.509)$ \\
2004 election year dummy variable & $0.763^{* * *}$ & -- & $0.244^{* *}$ \\
& $(3.341)$ & $0.765^{* * *}$ & $(2.110)$ \\
Regional and year dummy variables & Yes & $(3.352)$ & $\left(3.331^{* * *}\right.$ \\
& & Yes & Yes \\
Number of Observations & 150 & 150 & 150 \\
Log likelihood & -163.641 & -162.904 & -160.835 \\
\hline
\end{tabular}

Notes: Dependent variable is the number of presidential disasters declared in state $i$ in year $t$. Absolute $t$-statistics in parentheses. The coefficient on per capita income is interpreted per $\$ 10,000$ change.

$* * *, * *$, and $*$ denote significance at $1 \%, 5 \%$, and $10 \%$ respectively. 
TABLE 2

FEMA Oversight Committees and Average Membership

\section{Average Number of}

Members 2003-2005

\begin{tabular}{lc}
\hline $\begin{array}{l}\text { House of Representatives } \\
\text { House Appropriations Subcommittee } \\
\text { on Homeland Security }\end{array}$ & 16 \\
$\quad \begin{array}{l}\text { House Select Committee on Homeland } \\
\text { Security }\end{array}$ & 30 \\
$\begin{array}{l}\text { Senate } \\
\text { Senate Appropriations Subcommittee } \\
\text { on Homeland Security }\end{array}$ & 16 \\
$\quad \begin{array}{l}\text { Senate Committee on Homeland } \\
\text { Security and Government Affairs }\end{array}$ & 17 \\
\hline
\end{tabular}

Source: Subcommittee membership by state for each legislator is from the Congressional Staff

Directory, FEMA oversight committees from Foley and Rudman (2004). 
TABLE 3

Determinants of State-level FEMA Disaster Expenditures, Tobit Coefficients

\begin{tabular}{|c|c|c|c|}
\hline Variable & Model (1) & Model (2) & Model (3) \\
\hline Constant & $\begin{array}{c}-1,013,283,135 * * * \\
(4.667)\end{array}$ & $\begin{array}{c}-1,096,178,106 * * * \\
(4.810)\end{array}$ & $\begin{array}{l}-1,072,236,024^{* * *} \\
\quad(4.644)\end{array}$ \\
\hline Insurance property claims from disasters (\$) & $\begin{array}{c}0.034 * * * \\
(4.284)\end{array}$ & $\begin{array}{c}0.039 * * * \\
(4.398)\end{array}$ & $\begin{array}{c}0.039 * * * \\
(4.341)\end{array}$ \\
\hline Number of presidential disasters declared & $\begin{array}{l}418,705,827 * * * \\
\quad(6.297)\end{array}$ & $\begin{array}{l}427,798,423^{* * *} \\
\quad(6.356)\end{array}$ & $\begin{array}{l}425,465,461^{* * *} \\
(6.355)\end{array}$ \\
\hline $\begin{array}{l}\text { Total number of legislators on FEMA } \\
\text { oversight committees }\end{array}$ & $\begin{array}{l}30,555,759 \\
(0.666)\end{array}$ & 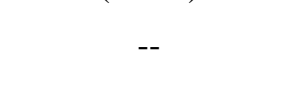 & 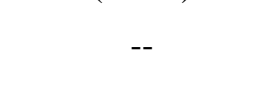 \\
\hline $\begin{array}{l}\text { Number of legislators on Senate oversight } \\
\text { committees }\end{array}$ & -- & $\begin{array}{c}115,723,791 \\
(1.408)\end{array}$ & -- \\
\hline $\begin{array}{l}\text { Number of legislators on House of } \\
\text { Representatives oversight committees }\end{array}$ & -- & $\begin{array}{c}2,147,206 \\
(0.041)\end{array}$ & -- \\
\hline $\begin{array}{l}\text { Number of legislators on the House } \\
\text { Appropriations Subcommittee on Homeland } \\
\text { Security }\end{array}$ & -- & (-), & $\begin{array}{l}-100,219,343 \\
(0.741)\end{array}$ \\
\hline $\begin{array}{l}\text { Number of legislators on the House Select } \\
\text { Committee on Homeland Security }\end{array}$ & -- & -- & $\begin{array}{l}29,360,585 \\
(0.479)\end{array}$ \\
\hline $\begin{array}{l}\text { Number of legislators on the Senate } \\
\text { Appropriations Subcommittee on Homeland } \\
\text { Security }\end{array}$ & -- & -- & $\begin{array}{l}127,067,452 \\
(0.903)\end{array}$ \\
\hline $\begin{array}{l}\text { Number of legislators on the Senate } \\
\text { Committee on Homeland Security and } \\
\text { Government Affairs }\end{array}$ & -- & -- & $\begin{array}{l}118,721,355 \\
(1.238)\end{array}$ \\
\hline 2004 election year dummy variable & $\begin{array}{l}31,979,609 \\
(0.231)\end{array}$ & $\begin{array}{l}58,950,770 \\
(0.423)\end{array}$ & $\begin{array}{l}35,116,977 \\
(0.247)\end{array}$ \\
\hline Regional and year dummies & Yes & Yes & Yes \\
\hline $\begin{array}{l}\text { Number of Observations } \\
\text { Log likelihood }\end{array}$ & $\begin{array}{c}150 \\
-1923.45\end{array}$ & $\begin{array}{c}150 \\
-1922.68\end{array}$ & $\begin{array}{c}150 \\
-1922.34\end{array}$ \\
\hline
\end{tabular}

Notes: Dependent variable is FEMA disaster expenditures. Absolute $t$-statistics in parentheses. Each coefficient is interpreted as the impact on FEMA expenditures given nonzero (positive) levels of FEMA disaster expenditures. The sample period is 2003 to 2005.

$* * *, * *, *$ denote significant at $1 \%, 5 \%$, and $10 \%$, respectively. 
TABLE 4

Determinants of State-level FEMA Disaster Expenditures, Marginal Effects

\begin{tabular}{lccc}
\hline Variable & Model (1) & Model (2) & Model (3) \\
\hline Constant & $-320,348,337 * * *$ & $-342,586,042^{* * *}$ & $-334,489,285^{* * *}$ \\
Insurance property claims from disasters $(\$)$ & $(4.888)$ & $(5.039)$ & $(4.853)$ \\
& $0.011^{* * *}$ & $0.012^{* * *}$ & $0.012^{* * *}$ \\
Number of presidential disasters declared & $(3.873)$ & $(4.005)$ & $(3.956)$ \\
& $132,373,382^{* * *}$ & $133,698,865^{* * *}$ & $132,726,037^{* * *}$ \\
Total number of legislators on FEMA & $(6.170)$ & $(6.238)$ & $(6.223)$ \\
oversight committees & $9,660,169$ & -- & -- \\
Number of legislators on Senate oversight & $(0.663)$ & $36,166,892$ & -- \\
committees & -- & $(1.404)$ & -- \\
Number of legislators on House of & & 671,061 & $(0.041)$ \\
Representatives oversight committees & -- & -- & $-31,263,915$ \\
Number of legislators on the House & & & $(0.742)$ \\
Appropriations Subcommittee on Homeland & -- & -- & $9,159,179$ \\
Security & & & $(0.477)$ \\
Number of legislators on the House Select & -- & -- & $39,639,315$ \\
Committee on Homeland Security & & & $(0.902)$ \\
Number of legislators on the Senate & -- & -- & $37,035,709$ \\
Appropriations Subcommittee on Homeland & & & $(1.236)$ \\
Security & -- & $18,423,750$ & $10,954,913$ \\
Number of legislators on the Senate & & $(0.422)$ & $(0.247)$ \\
Committee on Homeland Security and & $10,110,318$ & Yes & Yes \\
Government Affairs & $(0.231)$ & 150 & 150 \\
2004 election year dummy variable & Yes & -1922.68 & -1922.34 \\
Regional and year dummies & 150 & &
\end{tabular}

Notes: Dependent variable is FEMA disaster expenditures. Absolute $t$-statistics in parentheses. Each marginal effect reflects the impact on the expected amount of disaster expenditures, as each variable impacts the probability of a disaster being declared and the level of expenditures. The sample period is 2003 to 2005.

$* * *, * *, *$ denote significant at $1 \%, 5 \%$, and $10 \%$, respectively. 
FIGURE 1 - Number of Disasters Declared by President ${ }^{7}$

Ronald Reagan

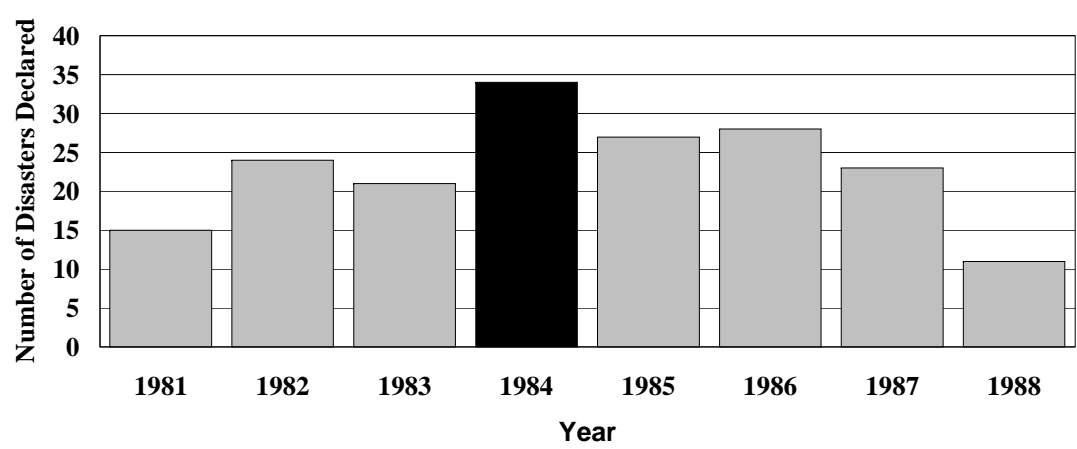

Bill Clinton

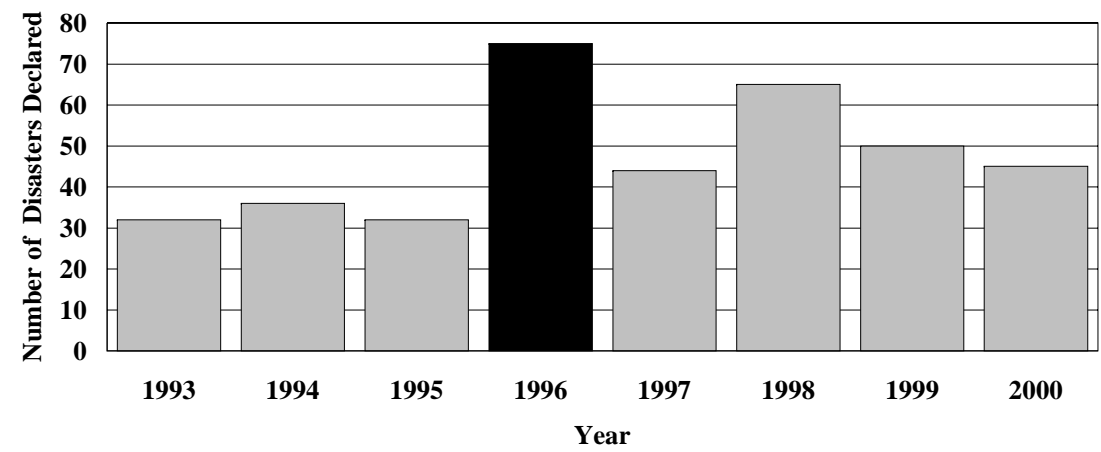

George Bush

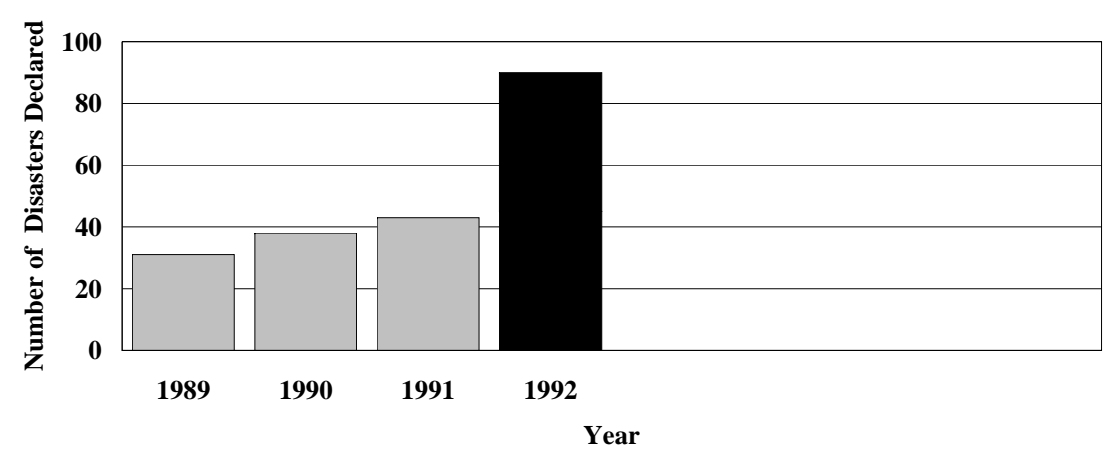

George W. Bush

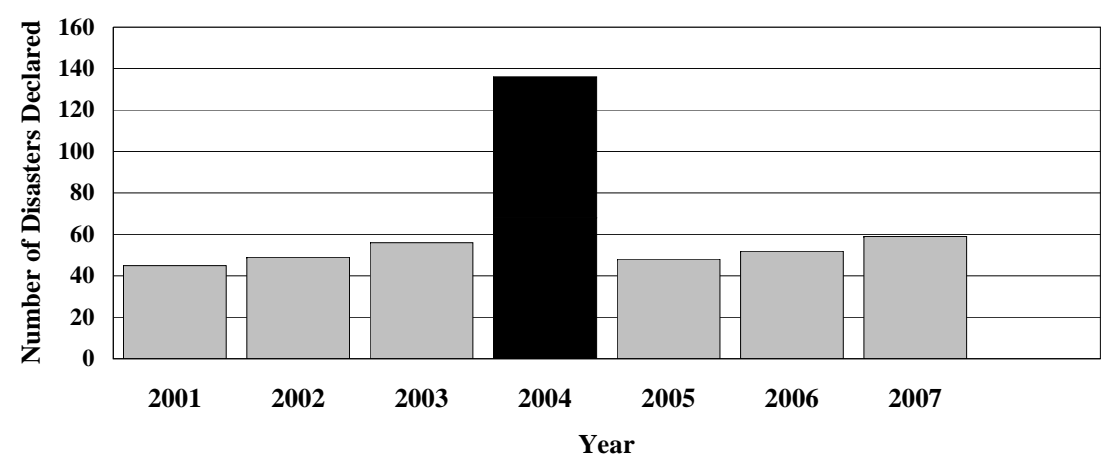

Notes: Black bar signifies reelection year. 2007 data are as of December 5, 2007.

\footnotetext{
${ }^{7}$ Source: FEMA webpage (http://www.fema.gov/news/disaster_totals_annual.fema). Last accessed December 5, 2007.
} 


\section{Dependent Variable:}

Number of presidential disasters declared

(1)

FEMA disaster expenditures (1)

The number of disasters declared in

state $i$ in year $t$

FEMA disaster expenditures in state $i$

in year $t(\$)$
0.907

(0.979)

$71,331,316$

$(495,015,050)$

\section{Independent Variables:}

Number of presidential disasters declared

(1)

Insurance property claims (2)

Per capita income (3)

Electoral importance (4)

Total number of legislators (5)

Legislator committee membership (5)

Governor from same political party as president (5)

Percent of Congress same party as president (5)

2004 election year dummy variable (6)

Regional and year dummy variables (6)

The number of disasters declared in

state $i$ in year $t$

Insurance property claims from

$5,606,887,620$

disasters (\$)

Real per capita income

$(6,937,640,880)$

32846.962

(4697.224)

Expected electoral votes for each

state $i$, calculated as Electoral

Votes $_{i}^{*} Y_{i}$, where $Y_{i}=1-4^{*}\left(X_{i}\right.$ -

$0.5)^{2}$, where $X_{i}$ is the percent of the

popular vote in the 2004 election for

Kerry in state $i$

Total number of legislators in both

the Senate and the House of

1.153

Representatives in the committees

overseeing FEMA

Legislator membership in the House

Appropriations Subcommittee on

Homeland Security, House Select

Committee on Homeland Security,

Senate Appropriations Subcommittee

on Homeland Security, and Senate

Committee on Homeland Security

and Government Affairs.

State's governor is from the same

political party as the current

incumbent president at time $t$

0.560

(0.498)

Number of Congress members from

the same political party as the current

incumbent president at time $t$ divided

0.536

(0.267)

by the total Congress membership

An indicator variable that equals 1

0.333

for data from 2004

New England, Mid-Atlantic, East

North Central, West North Central, South Atlantic, East South Central, West South Central, Mountain, and Pacific (omitted).

1. Data obtained from FEMA.

2. American Insurance Services Group, Property Claim Services.

3. U.S. Department of Commerce, Bureau of Labor Statistics, Washington, D.C.

4. Congressional Quarterly, Congressional Staff Directory.

5. U.S. Department of Commerce, Census Bureau, Washington, D.C. 